The amount of feed required to produce a dozen eggs has been reduced by some 12-15 per cent. There is also evidence of rising efficiency in crop production.

The best simple measure of the general rise of efficiency is found in the output per man, which has probably risen about 70 per cent in the last seventy years. From 1925 to 1939 the increase was very rapid. Different criteria of efficiency may be applied by interested parties. If agriculturists as a community have to apply any single standard to production they will judge it by the net output per man (gross output less cost of raw materials and depreciation of equipment), for it is this which determines the possibilities of their standards of remuneration and of living. Having set a high standard of output per man, each elass can bargain for its distribution with the assistance of any social forces they can draw to their aid. But with a low standard of output the standard of remuneration of one or more of the classes, and possibly all, must be low.

The general practice seems to have been to make international comparisons mainly in terms of yields or outputs per acre. But recently there has been a change, and other tests have been applied. On the information now available, it appears that Great Britain will take different positions in an international order of productivity according to the test applied. In a list of twelve countries-New Zealand, Australia, Great Britain, U.S.A., Denmark, Canada, The Netherlands, Belgium, Switzerland, France, Germany, Eire -the position of Great Britain is : (1) value of output per acre, seventh; (2) persons fed per acre (on cash value basis), sixth; (3) persons fed per worker, third (excelled only by Australia and New Zealand); (4) value of output per worker, third (again excelled only by New Zealand and Australia). In a test with seven European countries-Great Britain, Germany, France, Denmark, Belgium, The Netherlands, and Switzerland-the position of Great Britain is : (1) value of gross and net output per acre, seventh; (2) value of output per worker, first ; (3) average income per whole-time person engaged, almost certainly first.

But in case there is a tendency still to judge yields or outputs per unit of superficial area of land, that is, per acre, it may be pointed out that among the seven European countries, Great Britain is second only to Denmark in gross output per pound sterling annual (rental) values, and second only to France on net output per pound sterling annual (rental) values when a standard rate of interest is applied to capital values of land in each country. The rate of interest on capital values represented by gross rents or prevailing rates of interest on mortgages is higher in Great Britain than in any of the European countries listed. Measuring gross and net outputs against annual values of land as determined by the prevailing interest rate in each country, which varies between about $\mathbf{2 \cdot 2}$ per cent in Belgium and about 5 per cent in Great Britain, this country stands fourth in the list.

If Great Britain wishes to retain an agricultural population, which will be satisfied and satisfactory from either economic or social points of view, it will continue to be necessary to maintain a high standard of net output per worker, and all other standards have to be fitted to this condition. Even in war-time we have to make the optimum use of labour ; we cannot afford to waste labour on unproductive land; we must use our labour where it will be most productive of the supplies of which the nation has the greatest need.
The nation will judge by the quantities and qualities of products offered for human use and consumption in relation to its requirements, normally expressed through the markets, but in war-time expressed through the administrative organs of the State (Ministries of Agriculture, Food and Supply). Beyond this the nation has never had any clear criteria. The interested but poorly informed public has many and often conflicting criteria. It wants reasonably cheap food, maximum employment of labour, maximum production from the land, more small holdings, higher if not maximum wages and better housing for farm workers. It wants more wheat for national defence, more milk and vegetables for health, more eggs and more and higher quality meats to stimulate appetites and to meet needs due to changes in industrial work, urban living, and standards of real incomes.

Specific tests are applicable for special purposes in certain circumstances. The agricultural system of each country is more or less fitted to its general economic and social conditions. The conditions established in one country are not necessarily to be sought by any other, and the standards applied in one country are not likely to have any real validity in any other, unless the general economic and social conditions are similar in both.

Perhaps the most acute controversy about standards of production and efficiency in the future will turn on the efficiency of large farms. Past studies of the smaller and larger farms in Great Britain have usually shown that the smaller farms had the higher outputs per acre and the lower outputs per man. But in any discussion of this problem it must be remem. bered that few of the large agricultural enterprises in the country have been organized on unitary holdings, and also that there is no public information on the details of organization, inputs and outputs of the best of the large enterprises in Great Britain. Before any firm judgment can be made on the relative economic and social results of the largest, the medium and the small enterprises, we need much more information on the largest enterprises. At present information is practically limited to the small and mediumsized businesses.

A further caveat must also be entered. Even if it were proved that the results of the larger enterprises now in existence are not any better than those of the medium-sized or other groups, that would not prove that large unitary enterprises could not be designed, organized and operated to yield highly satisfactory results.

\section{GEOLOGICAL MAKING OF INDIA}

$M^{R}$

R. D. N. WADIA, author of the well-known "Geology of India for Students", retired from the Geological Survey of India in 1938, and shortly after took up the appointment of mineralogist to the Government of Ceylon. $\mathrm{He}$ was president of the Geological Section of the Indian Science Congress at its jubilee session in Calcutta in 1938, and became general president of the whole Congress at the twenty-ninth session held this last January at Baroda; he is the third geologist to fill this position. During his Indian service Mr. Wadia was engaged mainly in the study and mapping of the postArchæan folded formations of north-western India, 
including Kashmir. In his present service, in Ceylon, he has been called upon to study the rocks at the other end of the geological scale, forming the Archæan basement. This exceptional diversity of opportunity has enabled him in his presidential address to the Indian Science Congress (Proc. 29th Ind. Sci. Cong., Part II, 3-23; 1942) to discuss with wide experience the "Making of India", in which he makes particular use of data derived from Ceylon, which, of course, is only a detached fragment of the Peninsula of India.

Mr. Wadia emphasizes the well-known general distinction between (I) the geologically speaking, recently folded extra-peninsular area of India, comprising the mountain festoons of Baluchistan and the North-West Frontier on the west, of the Himalaya to the north, and of the Assam-Burma ranges to the east; and (2) the geologically ancient and stable Peninsula, with its Archæan basement, superposed Purana and Gondwana sediments, and Deccan Trap basalt flows, and the absence of any serious folding movements since pre-Cambrian times. Such mountains as now exist in the Peninsula of India are either deeply eroded remnants of pre-Cambrian ranges, such as the Aravallis and the Eastern Ghats, probably (in the reviewer's opinion) re-elevated, or are plateau mountains due to denudation, with block uplift and depression, as in the Deccan Trap section of the Western Ghats.

In the extra-peninsular area, compressive earth forces still prevail, as instanced by the frequency of serious earthquakes; while in the Peninsula tensional forces with vertical uplift and depression have long prevailed, and serious earthquakes no longer occur. This essential difference between the extrapeninsular and the peninsular areas of India was noticed by W. T. Blanford, in the first edition of the "Manual of the Geology of India", so long ago as 1879 , and was recently emphasized by myself (Rec. Geol. Sur. India, 62, 408; 1930). As Mr. Wadia points out, this fundamental difference between the two main portions of the Indian sub-continent is due to the fact that it is composed of two crust-blocks of totally different history, namely, the Archæan shield of the Peninsula, which is a fragment of Gondwanaland, and the folded belt of the Himalaya representing the Tethys, which by their interaction have produced the Indo-Gangetic plains.

In Ceylon, the whole island is occupied by an Archæan crystalline terrane, except for Miocene rocks occurring mainly as a fringe on the northwestern edge, and a minute occurrence of Jurassic rocks. The central portion of the island is mountainous, rising to $8,292 \mathrm{ft}$. in Pedrotallagalla. Three well-marked terraces or peneplains have been described by Prof. F. D. Adams, and are recognized by Mr. Wadia. "These three terraces rise from the sea in two sharply cut steps or escarpments, the lower step about 1,000 feet above the coastal peneplain (which is very nearly a plain of marine denuda. tion) and the second step 3,000-4,000 feet above the latter to the third and highest peneplain" (p. 14). These escarpments are characterized by numerous waterfalls.

There are two possible explanations of these terraces. They may represent successive levels of denudation, in which case the lowest terrace is the youngest, and all that is required to explain this peculiarity in the orography of Ceylon is successive uplifts of the island as a whole, the mural scarps being due to the effects of differential erosion on beds of different powers of resistance. Or the terraces may be due to selective block uplift, and the mural scarps represent eroded fault scarps. The coastal terrace is then the oldest, and the mountein centre of the island the region of latest uplift. Adams, in his study of the geology of Ceylon (Canadian $J$. Research, 1, 425-465, 467-511; 1929), adopts the former explanation, and Mr. J. S. Coates, who was Mr. Wadia's predecessor as Government mineralogist, does not disagree with Adams in his "Geology of Ceylon" (Ceylon J. Sci., 19, Sect. B, Part 2, 101-186; 1935); nor does Coates's geological map, which is admittedly only a sketch map, show any necessity for block faulting. Mr. Wadia, in his address, discusses only the second possibility and states : "The field geological work so far carried out in this area indicates, beyond doubt, that the Ceylon mountains are not the undenuded passive remnants left out of an old table-land, but have been 'created' by positive earth-movements, lifting them vertically in two intermittent, widely separated stages". In his view the second peneplain was elevated in post-Jurassic times, and the uppermost and central terrace in late Tertiary times.

In the absence of the evidence upon which Mr. Wadia bases his belief in selective block faulting, it is difficult for the reader to judge between these two possibilities. Adams's explanation seems so reasonable that the reader will probably prefer to follow him until Mr. Wadia produces his evidence, which he has deferred to an occasion more suitable than an address to a general audience. Should Mr. Wadia's detailed account carry conviction, then the credit for establishing this hypothesis of selective block-uplift to Ceylon will belong to him.

In his general discussion of the making of India, Mr. Wadia raises many points upon which there is scope for difference of opinion; lack of space prevents reference to them all. It is necessary, however, to demur to two passages in particular, namely, that (p. 9) which speaks of the "unpuckered and generally horizontally bedded rocks" of the peninsular crust. block of India, and the statement that Mount Everest is built of "this axial granite core". Many of the Archæan gneisses and schists of the Peninsula are as contorted and crumpled as any in the Himalaya; while Mount Everest has been shown by Odell and Wager to be composed largely of metamorphosed sedimentary rocks.

In the first part of his address, devoted to general matters, Mr. Wadia discusses the interactions of science and industry in India, and also the charge against science of "helping with its inventions and discoveries man's lower instincts and lust for power, possession and aggrandizement". This misuse of science is, of course, not due to the scientific man as such, and to check such perversion Mr. Wadia states (p. 5) that "it is time the hierarchy of pure science asserted its patent rights on the common pool of strategic science and, backed by its $1 \frac{1}{2}$ centuries of resolute strivings for the betterment of mankind, claim a determining share in the governments of the world. An international directorate of scientists, containing a due proportion of economists, engineers and industrialists, will, by adopting the technique and temper of science, govern the countries of the world better than the chancellors, diplomats and politicians who for the past 5,000 years have failed to bring harmony in human relations, but have sig. nally succeeded in making history one record of recurrent wars." $\quad$ L. L. FERMor. 